\title{
Pembelajaran Sains di Madrasah Berbasis Tradisi Islam (Gerak Benda Menurut Ibn Bajah)
}

\author{
Ade Putri, Dalilah Nur Alip \\ Universitas Islam Negeri Sunan Gunung Djati Bandung, Indonesia
}

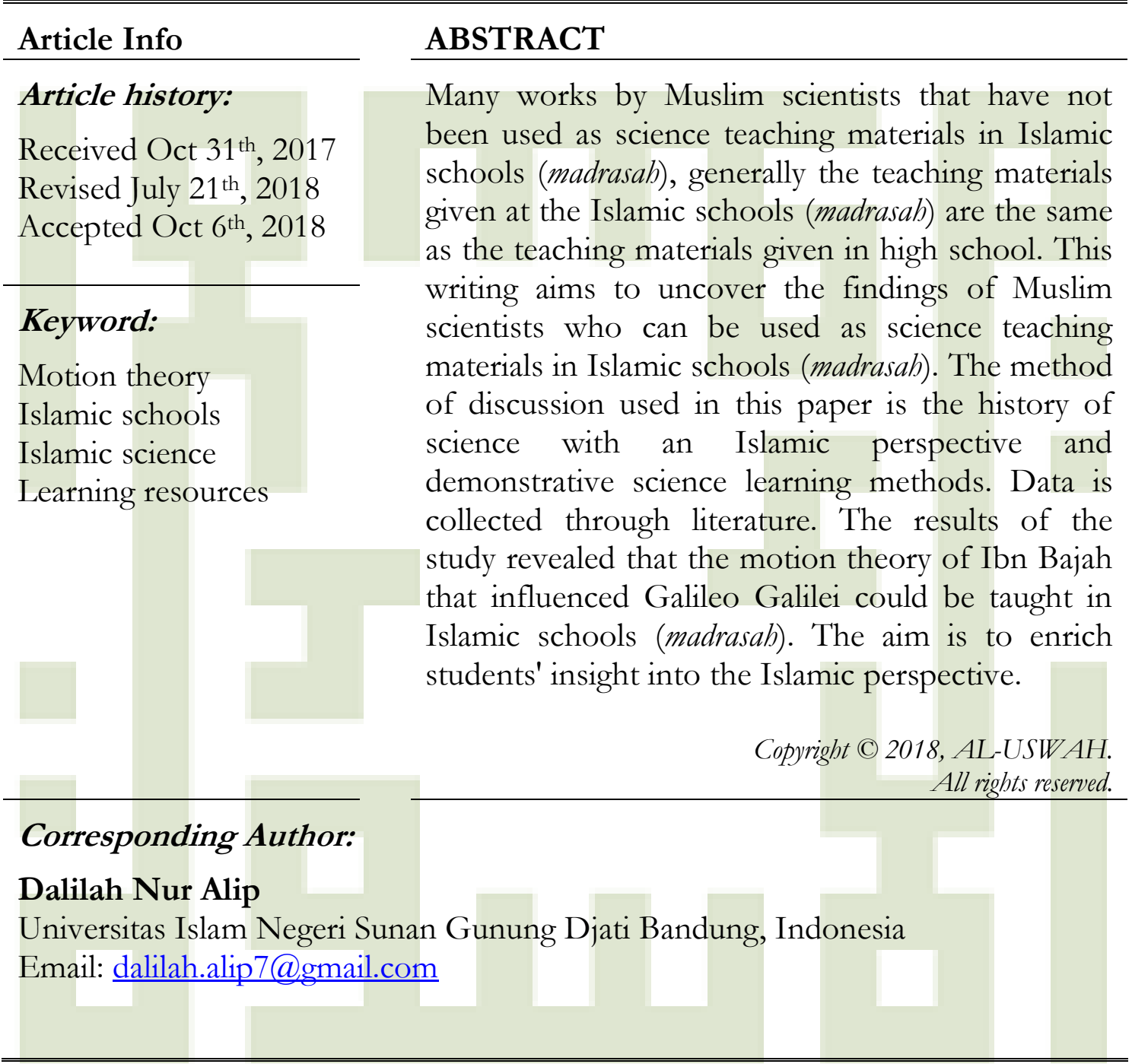

\section{PENDAHULUAN}

Pendidikan merupakan bagian yang terpenting dalam kehidupan manusia yang sekaligus membedakan manusia dengan hewan. Manusia dikarunia Tuhan akal dan pikiran,

sehingga manusia mengetahui segala hakekat permasalahan dan sekaligus dapat membedakan antara yang baik dan yang buruk dalam dirinya maupun kehidupan masyarakat dan 
bangsa. ${ }^{1}$ Jika berbicara pendidikan, dalam konteks pendidikan yang dialami oleh bangsa Indonesia dewasa ini tidak akan pernah ada habisnya. Pendidikan adalah permasalahan yang tidak pernah putus karena menyangkut persoalan manusia dalam rangka memberi makna dan moral. Ada banyak hal yang harus dibenahi menyangkut persoalan yang datang dari luar dunia pendidikan, mulai dari masalah birokrasi pendidikan yang masih tumpang tindih, simpang siur dan tidak terkoordinasi dengan baik sampai dengan masalah internal pendidikan itu sendiri, yakni mengenai konsep pendidikan dan aplikasi praksis menciptakan pendidikan yang tepat dan akurat bagi kondisi bangsa.

Bangsa Indonesia sebagai bangsa yang mayoritas penduduknya adalah pemeluk agama Islam, dalam rangka pelestarian dan pengembangan kebudayaan yang mengedepankan dan menjunjung tinggi nilai moralitas melalui cipta karya manusia, dengan peng-optimalan potensinya, mempunyai andil yang sangat besar untuk mewujud-kannya. Umat Islam mempunyai tanggung jawab yang besar akan hal itu. Namun di tengah pusaran berbagai ideologi, pandangan, teori pendidikan yang berbasis kultur peradaban barat, seperti liberalisme, esensialisme, progresifisme, nativisme, empirisme dan konvergensi wacana pendidikan Islam nampaknya selalu marginal.

${ }^{1}$ Tatang M. Amrin, et.al., Manajemen Pendidikan (Yogyakarta: 2011, UNY Press), 7.
Ide-ide dan teori pendidikan yang lahir dari konsepsi Islam sangat sulit dijual keruang publik. Orang berfikir bahwa pendidikan Islam lebih berurusan dengan wilayah terbatas dari sebuah aktifitas manusia terkait dengan perbaikan moral. ${ }^{2}$

Kemudian dewasa ini, telah muncul gejala yang kurang baik yang menimbulkan kegoncangan dalam kehidupan keluarga, masyarakat dan bangsa, di antaranya adalah kenakalan remaja, tawuran, korupsi oleh para pejabat negara. Salah satu faktor penyebab timbulnya kenakalan remaja, karena kurangnya perhatian orang tua terhadap anak, utamanya pembinaan akhlak. Pembinaan akhlak adalah mutiara hidup yang membedakan makhluk manusia dan makhluk hewani. Manusia tanpa akhlak akan hilang derajat kemanusiaannya sebagai mahkluk mulia, sesuai dengan fitrah, dan yang memiliki peran sebagai hamba dan khalifah Allah di muka bumi. Oleh karena itu, nilai-nilai akhlak harus ditanamkan sejak dini baik melalui pendidikan keluarga, masyarakat, maupun lembaga pendidikan formal yaitu sekolah. Suatu bangsa akan jaya dan terkenal bukan ditentukan oleh keluasan wilayah, kekayaan sumber daya alam, serta kuantitas penduduknya, akan tetapi adalah karena kualitas akhlak atau tingginya nilainilai peradaban yang dimilikinya oleh peserta didik di Indonesia.

${ }^{2}$ Aziza Aryati, "Pemikiran Pendidikan al-Mawardi," At-Ta'lim, Vol. 15, No. 1, (Januari 2016). 
Jika dilihat dengan kaca mata kita bahwa pendidikan, hal yang demikian itu mungkin terjadi, karena memang selama ini pendidikan kita lebih berkonsentrasi kepada pembangunan ekonomi pragmatis dengan orientasi keuntungan jangka pendek yang lebih kasat mata, imbasnya pada pendidikan ialah terbengkalainya pendidikan Nasional kita, pantaslah apa yang dikatakan Ahmad Tafsir bahwa pendidikan kita dianggap gagal karena tidak mampu menghasilkan manusia berkualitas, beriman, dan berakhlak mulia di masyarakat.

Kemudian jika ditelaah lebih dalam nilai nilai Islam itu harus dimiliki oleh setiap pendidik, seperti halnya etika, moral, tawadhu, rendah hati, beserta akhlakul karimah, di mana seorang pendidik harus memiliki sikap profesional, sikap sosial, dan pengetahuan yang banyak sehingga dalam proses pembelajaran yang berlangsung di setiap lembaga agar membawa hasil yang lebih baik dan memiliki ouput bisa diterima di masyarakat banyak.

\section{BIOGRAFI AL-MAWARDI}

Ulama penganut Mazhab Syafi'i ini bernama lengkap Abu al-Hasan Ali bin Habib al-Mawardi al-Bashry, panggilannya Abu al-Hasan, gelarnya al-Mawardi, diambil dari gelar keluarganya yang menjual ma`al-ward (air mawar). ${ }^{3}$ Lahir di kota pusat peradaban Islam klasik, Bashrah

${ }^{3}$ Al-Mawardi, Al-Hawy al-Kabir, Jilid I (Beirut: Dar al-Fikr, 1994), 3.
(Irak) pada tahun $364 \mathrm{H}$. Al-Mawardi menerima pendidikan pertamanya di kota kelahirannya, ia belajar ilmu hukum dari Abu al-Qasim 'Abd alWahid al-Saimari. ${ }^{4}$

Di kota ini juga al-Mawardi sempat mempelajari hadis dari beberapa ulama terkenal seperti alHasan bin Ali bin Muhammad bin alJaily, Abu Khalifah al-Jumhy, Muhammad bin 'Adiy bin Zuhar alMarzy, Muhammad bin al-Ma'aly alAzdy serta Ja'far bin Muhammad bin al-Fadl al-Baghdadi. ${ }^{5}$ Menurut pengakuan muridnya, Ahmad Bin Ali al-Khatib ${ }^{6}$ bahwa dalam bidang hadis, al-Mawardi termasuk orang yang tsiqob. ${ }^{7}$ Selain mendalami bidang hadis, al-Mawardi juga mendalami bidang fiqh pada Syekh Abu alHamid al-Isfarayini. ${ }^{8}$

Sehingga ia tampil sebagai salah seorang ahli fiqh terkemuka dari Madzhab Syafi'i. Keahlian alMawardi selanjutnya juga dalam bidang sastra dan sya'ir, nahwu, filsafat dan ilmu sosial, namun belum dapat diketahui secara pasti dari mana ia mempelajari ilmu kebahasaan tersebut. Dalam waktu singkat ia telah menguasai dengan baik ilmu-ilmu agama tersebut. Setelah seluruh hayatnya diabdikan untuk dunia ilmu dan kemaslahatan umat, Sang Khaliq akhirnya memanggil al-Mawardi untuk selama-

4Ibid., 4.

5Ibid., 58.

'Ibid., 60.

${ }^{7}$ Al-Mawardi, Adab al-Dunya wa al-Din (Beirut: Dar al Fikr, 1995), 21.

8Ibnu Katsir, Al-Bidayah wa al-Nibayah (Cairo: Dar Al-Hadis, 1998), 3. 
lamanya pada usia 86 tahun yaitu pada tanggal 30 Rabi' ul-Awal $450 \mathrm{H}$, dan dimakamkan di Bab Harb Baghdad.?

\section{PEMIKIRAN AL-MAWARDI DALAM BIDANG PENDIDIKAN}

Pemikiran al-Mawardi dalam bidang pendidikan sebagian besar terkonsentrasi pada masalah etika hubungan guru dengan murid dalam proses belajar mengajar. Pemikiran ini dapat dipahami, karena dari seluruh aspek pendidikan, guru memegang peranan yang sangat penting, bahkan berada pada garda terdepan. Keberhasilan pendidikan sebagian besar bergantung kepada kualitas guru baik dari segi penguasaannya terhadap materi pelajaran yang diajarkan maupun cara menyampaikan materi pelajaran tersebut serta kepribadiannya yang baik, yaitu pribadi yang terpadu antara ucapan dan perbuatannya secara harmonis.

Al-Mawardi memandang sangat penting seorang guru harus memiliki sikap tawadhu' (rendah hati) serta menjauhi sikap 'ujub (besar kepala). Menurut al-Mawardi sikap tawadhu' akan menimbulkan simpatik dari para peserta didiknya, ${ }^{10}$ sedangkan sikap 'ujub akan menyebabkan guru kurang disenangi. ${ }^{11}$

${ }^{9}$ Al-Mawardi, Al-Hawy al-Kabir ..., 5.

${ }^{10} \mathrm{Al}-\mathrm{Mawardi}$, Adab al Dunya wa al-Din (Beirut: Dar al Fikr, t.th.), 80.

${ }^{11}$ Ibid., 99.
Sikap tawadhu' yang dimaksudkan al-Mawardi bukanlah sikap menghinakan diri atau merendahkan diri ketika berhadapan dengan orang lain, karena sikap ini akan menyebabkan orang lain meremehkannya. Sikap tawadhu' yang dimaksud adalah sikap rendah hati dan merasa sederajat dengan orang lain dan saling menghargai. Sikap demikian akan menumbuhkan rasa persamaan, menghormati orang lain, toleransi, serta rasa senasib dan cinta keadilan. $^{12}$

Dengan sikap tawadhu' tersebut, guru akan menghargai muridnya sebagai makhluk yang memiliki potensi, serta melibatkannya dalam kegiatan belajar mengajar. Prinsip ini sejalan dengan prinsip yang digunakan para pendidik di zaman modern, yaitu bahwa dalam kegiatan belajar-mengajar di masa sekarang seorang murid dan guru berada dalam kebersamaan.

Kemudian pada perkembangan selanjutnya sikap tawadbu' tersebut akan menyebabkan guru bersikap demokratis dalam menghadapi murid-muridnya. Sikap demokratis ini mengandung makna bahwa guru berusaha mengembangkan individu seoptimal mungkin. Guru tersebut menempatkan peranannya sebagai pemimpin dan pembimbing dalam proses belajar mengajar yang berlangsung dengan utuh dan luwes, di mana seluruh siswa terlibat di dalamnya.

${ }^{12}$ Ahmad Muhammad al-Hufi, Min Akblaq al-Nabi (Cairo: Al-Majlis al-A'la li Syu'uni al-Islamiyah, 1968), 283. 
Pelaksanaan prinsip demokratis di dalam kegiatan belajar mengajar dapat diwujudkan dalam bentuk timbal balik antara siswa dengan siswa dan antara siswa dengan guru. ${ }^{13}$ Selanjutnya al-Mawardi mengatakan bahwa seorang guru selain harus bersikap tawadhu', juga harus bersikap ikhlas. Secara harfiah berarti menghindari riya, sedangkan dari segi istilah ikhlas berarti pembersihan hati dari segala dorongan yang dapat mengeruhkannya. ${ }^{14}$

Keikhlasan ini ada kaitannya dengan motivasi seseorang. Sebagaimana diketahui bahwa ada guru yang mengajar karena motif ekonomi, memenuhi harapan orang tua, dorongan teman atau mengharapkan status dan penghormatan serta lainnya. Selain motif-motif tersebut seorang guru harus mencintai tugasnya. Kecintaan ini akan tumbuh dan berkembang apabila keagungan, keindahan dan kemuliaan tugas guru itu sendiri benar-benar dapat dihayati. Namun motif yang paling utama, menurut alMawardi, adalah karena panggilan jiwanya untuk berbakti kepada Allah SWT dengan tulus dan ikhlas. Lebih lanjut lagi ia mengatakan bahwa akhlak yang harus dimiliki para guru adalah menjadikan keridhaan dan pahala dari Allah SWT sebagai tujuan dalam melaksanakan tugas mengajar dan mendidik muridnya, bukan

\footnotetext{
${ }^{13 R u s y a n}$ A. Tabrani, Kemampuan Guru dalam Proses Mengajar (Bandung: Remaja Rosdakarya, 1994), 117.

${ }^{14}$ Ali bin Muhammad al-Jurjaniy, Kitab al-Ta'rifat (Beirut: Dar al-Kutub, 1978), 13.
}

mengharapkan balasan berupa materi. ${ }^{15}$

Dari pernyataan di atas bahwa memperlihatkan dengan jelas bahwa al-Mawardi menghendaki agar seorang guru benar-benar ikhlas dalam melaksanakan tugasnya. Menurutnya, bahwa tugas mendidik dan mengajar harus diorientasikan kepada tujuan yang luhur, yakni keridhaan Allah SWT. Sebagai konsekuensi dari orientasi semacam ini adalah pelaksanaan tugas guru dengan sebaik-baiknya serta penuh tanggung jawab.

Kemudian al-Mawardi melarang seseorang mengajar dan mendidik atas dasar motif ekonomi. Dalam pandangannya bahwa mengajar dan mendidik merupakan aktifitas keilmuan, sementara ilmu itu sendiri mempunyai nilai dan kedudukan yang tinggi, yang tidak dapat disejajarkan dengan materi. Dalam kaitan ini al-Mawardi mengatakan bahwa sesungguhnya ilmu adalah puncak segala kenikmatan dan pemuas segala keinginan. Siapa yang mempunyai niat ikhlas dalam ilmu, maka ia tidak akan mengharap mendapatkan balasan dari ilmu itu. ${ }^{16}$ Itulah sebabnya dalam mendidik dan mengajar seseorang harus semata-mata mengharapkan ridha Allah. Apabila yang dituju dari tugas mengajarnya itu adalah materi, maka ia akan mengalami kegoncangan ketika ia merasa bahwa kerja yang dipikulnya tidak seimbang dengan

${ }^{15} \mathrm{Al}$-Mawardi, Adab al-Dunya ..., 4.

${ }^{16}$ Muntasir M. Sholeh, Mencari Evidensi Islam (Jakarta: Rajawali, 1985), 141. 
hasil yang diterimanya. Selain itu ia sengat peka terhadap hal-hal atau persoalan yang ditemukan dalam tugasnya, misalnya soal administrasi, kenaikan pangkat, hubungan dengan kepala sekolah dan sebagainya. Tindakan dan sikapnya terhadap anak didik akan terpengaruh pula. Hal ini selanjutnya dapat merusak atau mengurangi hasil atau nilai pendidikan yang diterima anak didik. ${ }^{17}$

Maka dengan demikian, dari uraian di atas kiranya dapat dimaknai keikhlasan seorang guru dalam mendidik adalah kesadaran akan pentingnya tugas, sehingga dengan kesadaran tersebut ia akan terdorong untuk mencapai hasil yang maksimal. Keikhlasan inilah akan menentukan keberhasilan tugasnya sehari-hari, tanpa merasakannya sebagai suatu beban, melainkan sebaliknya justru akan merasa bahagia, penuh harapan dan motivasi, karena dari tugas mengajar dan mendidiknya itu, ia kelak akan mendapatkan pahala yang setimpal dari Allah SWT.

Berdasarkan sikap ikhlas tersebut, maka seorang guru akan tampil melaksanakan tugasnya secara professional. Hal ini ditandai oleh beberapa sikap sebagai berikut: pertama, selalu mempersiapkan segala sesuatu yang diperlukan guna mendukung pelaksanaan proses belajar mengajar, seperti dalam penguasaan materi (bahan pelajaran), pemilihan metode, penggunaan sumber dan media pengajaran,

17Zakiyah Derajat, Kepribadian Guru (Jakarta: Bulan Bintang, 1980), 14. pengelolaan kelas dan lain sebagainya. Kedua, disiplin terhadap peraturan dan waktu, dalam keseluruhan hubungan sosial dan profesionalnya, seorang guru yang ikhlas akan bertindak tepat dalam janji dan penyelesaian tugasnya. Guru yang ikhlas akan mampu mengelola waktu bekerja dan waktu lainnya dengan perencanaan yang rasional dan disiplin yang tinggi. Ketiga, penggunaan waktu luang akan diarahkan untuk kepentingan profesionalnya. Guru yang ikhlas, keseluruhan waktunya akan digunakan secara efisien, baik dengan tugas keguruan maupun dalam pengembangan kariernya, sehingga ia akan mencapai peningkatan. Bila sebagian waktu luang digunakan untuk hal-hal yang berada di luar tugasnya, maka guru yang ikhlas akan menggunakannya secara bijaksana dan produktif serta tidak mengganggu tugas pokoknya. Keempat, ketekunan dan keuletan dalam bekerja. Guru yang ikhlas akan menyadari pentingnya katekunan dan keuletan bekerja dalam pencapaian keberhasilan tugasnya. Oleh karenanya ia akan selalu berusaha menghadapi kegagalan tanpa putus asa dan mengatasi segala kesulitan dengan penuh kesabaran, sehingga akhirnya program pendidikan yang telah ditetapkannya akan berjalan sebagaimana mestinya serta mencapai sasaran.

Di samping itu, keuletan dan ketekunan yang ditampilkan guru sebagai pribadi yang utuh, akan terbiasa melakukan suatu tugas atau 
pekerjaan yang ulet, tekun, penuh kesungguhan dan ketelitian. Kelima, memiliki daya kreasi dan inovasi yang tinggi. Hal ini timbul dari kesadaran akan semakin banyaknya tuntutan dan tantangan pendidikan masa mendatang, sejalan dengan kemajuan imu pengetahuan dan teknologi. Guru yang ikhlas akan terus mengevaluasi dan mengadakan perbaikan proses belajar mengajar yang telah digunakannya selama ia bertugas. Lebih jauh dari itu, guru tersebut akan mempelajari kelemahan dan kelebihan dari berbagai teori dan konsep yang dapat digunakan dalam proses belajar mengajar yang diterapkan para pendahulunya, untuk selanjutnya dilakukan penyempurnaan dan pengayaan. Mengingat tugas keguruan tidak dapat dipolakan secara mekanis, eksak dan dengan resep tunggal serta tak terbatasnya variasi tindakan keguruan, maka guru dituntut untuk mampu bertindak kreatif.

Dalam kaitannya dengan keikhlasan tersebut, al-Mawardi juga berbicara tentang gaji. Dalam hubungan ini, al-Mawardi mengatakan bahwa di antara akhlak yang harus dimiliki seorang guru adalah membersihkan diri dari pekerjaan-pekerjaan syubhat dan menguras tenaga. Hendaknya ia merasa cukup atas penghasilan yang dicapai dengan mudah, dari pada penghasilan yang dicapai dengan susah payah. Guru harus meninggalkan pekerjaan yang syubhat, karena perbuatan syubhat akan berakibat dosa. Pahala lebih baik dari dosa dan kemuliaan lebih pantas dibandingkan dengan kehinaan. ${ }^{18}$

Dari pernyataan al-Mawardi di atas mengisyaratkan bahwa bagian dari kegiatan mendidik adalah memberikan teladan. Oleh karena itu dalam memberikan ilmu kapada muridnya, seorang guru dituntut memiliki kejujuran dengan menerapkan apa yang diajarkan dalam kehidupan pribadinya. Dengan kata lain, seorang guru harus konsekuen dalam menjaga keharmonisan antara ucapan, larangan dan perintah dengan amal perbuatannya sendiri. Selain sebagai teladan, seorang guru juga harus tampil sebagai penyayang. Guru merupakan aktor kedua setelah orang tua dalam memberikan modal atau bekal dasar kepada anakanaknya.

Oleh karenannya, guru sebagai pendidik profesional dituntut untuk berperan sebagai orang tua di sekolah. Dengan kedudukannya yang demikian, maka seorang guru harus memiliki sifat kasih sayang dan lemah lembut terhadap muridnya. Dalam hubungan ini, al-Mawardi mengatakan bahwa di antara akhlak seorang guru adalah tidak berlaku kasar kepada muridnya, tidak boleh menghina murid yang sedang berkembang, tidak boleh memandang rendah murid-muridnya. Karena semua itu akan membuat mereka lebih tertarik, terkesan, dan bersemangat. ${ }^{19}$
18Al-Mawardi, Adab al-Dunya..., 112.

19Ibid., 142. 
Selanjutnya al-Mawardi menegaskan tentang tugas dan peran guru sebagai pembimbing. Bimbingan dapat diartikan sebagai kegiatan memantau murid dalam perkembangannya dengan jalan menciptakan lingkungan dan arahan sesuai dengan tujuan pendidikan. Sedangkan dari segi bentukya bimbingan tersebut dapat berupa pemberian petunjuk, teladan, bantuan, latihan, penerangan, pengetahuan, pengertian, kecakapan dan keterampilan, nilai-nilai, norma serta sikap yang positif. Dalam kaitan ini al-Mawardi mengatakan, di antara kewajiban guru adalah memberikan nasihat atau bimbingan kepada muridnya, kasih sayang, mempermudah jalan bagi muridnya, berusaha keras menolong dan membantu muridnya. Semua itu akan menghasilkan pahala yang besar, keluhuran namanya, serta semakin bertambah dan menyebar ilmunya. ${ }^{20}$

Bentuk-bentuk bimbingan tersebut selanjutnya adalah dengan jalan membantu murid-murid untuk mengembangkan pemahaman diri sesuai dengan kecakapan, minat, pribadi, hasil belajar serta kesempatan yang ada, membantu proses sosialisasi dan sensivitas kepada kebutuhan orang lain, mengembangkan motif-motif intrinsik dalam belajar sehingga tercapai kemajuan pengajaran, memberikan dorongan dalam pengarahan diri, pemecahan masalah, pengambilan keputusan, dan keterlibatan diri dalam proses

20Ibid., 113. pendidikan, mengembangkan nilai dan sikap secara menyeluruh serta perasaan sesuai dengan penerimaan diri sendiri, memahami tingkah laku manusia, membantu murid-murid untuk memperoleh kepuasan pribadi dan dalam penyesuaian diri secara maksimum terhadap masyarakat serta membantu aspek fisik, mental dan sosial. $^{21}$

\section{POLA INTERAKSI PEMBELAJARAN}

Menurut Al-Mawardi, untuk mencapai keberhasilan yang maksimal dalam proses pendidikan, harus diperhatikan sembilan perkara yang akan berpengaruh pada proses tersebut. Adapun kesembilan perkara tersebut yaitu: pertama, akal yang dapat menangkap hakikat dari sesuatu. Kedua, kecerdasan yang dapat menyingkap rahasia pengetahuan. Ketiga, kekuatan ingatan untuk menyimpan memori-memori pengetahuan. Keempat, semangat yang dapat memalingkan diri dari rasa malas dan bosan. Kelima, mencukupkan pada mempermudah materi yang tidak perlu di buat sulit. Keenam, konsentari. Ketujuh, tidak adanya penghalang yang dapat mengacaukan. Kedelapan, pendidikan dilaksanakan sepanjang hayat. Kesembilan, adanya bimbingan guru dalam proses pendidikan. ${ }^{22}$

Dengan demikian untuk memperoleh ilmu yang baik seorang

21 Zuhairini, Sejarah Pendidikan Islam (Jakarta: Bumi Aksara, 1992), 65.

22Al-Mawardi, Adab al-Dunya..., 74-75. 
murid harus selalu berusaha ada di dekat guru dan selalu hormat kepada guru walaupun si murid lebih tinggi derajadnya. Menurut al-Mawardi, guru lebih berhak untuk dihormati karena ilmunya. Dalam proses pembelajaran, menurut al-Mawardi, seorang guru harus mengembangkan suasana lapang yang memungkinkan murid untuk mengapresiasikan potensinya. Selain itu seorang guru tidak boleh menjadikan pembelajaran terfokus pada dirinya (teaching center).

Guru harus bisa mengembangkan pola interaktif dalam pembelajaran karena masing-masing siswa membawa potensi sendirisendiri, dan dalam pembelajaran guru tidak boleh merasa paling menguasai materi, karena dapat dimungkinkan murid mengetahui informasi lebih dalam dari guru atau justru kebenaran akan hakikat pengetahuan itu datang dari murid, sehingga guru pun dapat mengambil manfaat dari pola pembelajaran tersebut. Pola hubungan interaksi antara pendidik dan anak didik yang dikembangkan oleh al-Mawardi ini, agaknya menyiratkan pada sebuah pemahaman bahwa pendidikan itu lebih ditekankan pada aspek anak didik. Guru dalam proses pendidikan ini berfungsi sebagai fasilitator dan pembimbing untuk mengarahkan murid pada pengembangan potensi yang dimilkinya. Peran guru bukan hanya sebagai transmitor pengetahuan (knowledge) kepada anak didik tersebut.

\section{NILAI-NILAI PENDIDIKAN ISLAM}

5.1. Pengertian Nilai

Nilai telah diartikan oleh para ahli dengan banyak pengertian. Pengertian yang satu berbeda dengan pengertian yang lain karena nilai mempunyai hubungan yang sangat erat dengan pengertian-pengertian dan aktifitas manusia yang kompleks dan sulit ditentukan batasannya. Milton Rokeach dan James Bank mengemukakan bahwa nilai adalah suatu tipe kepercayaan yang berada dalam ruang lingkup sistem kepercayaan dalam mana seseorang bertindak atau menghindari suatu tindak-an, atau mengenai yang pantas atau tidak pantas. ${ }^{23}$

Dari definisi di atas bahwa nilainilai sering digunakan secara sempit dalam kehidupan sehari-hari. Dari sini dapat diketahui bahwa istilah nilai mempunyai pegertian yang sangat sama dengan kebaikan. Dalam masalah ini yang terpenting adalah relasi antara yang baik dengan kewajiban. Misalnya, guru dalam berhubungan atau berkomunikasi dengan murid harus mempunyai tatanan nilai yang baik, sehubungan dengan tugas dan wewenang dia sebagai seorang guru. Seorang anak atau peserta didik akan memperhatikan dan menirunya.

\subsection{Macam-macam Nilai}

Menurut M. Chabib Thoha, dalam bukunya Kapita Selekta

${ }^{23}$ M. Chabib Thoha, Kapita Selekta Pendidikan Islam (Yogyakarta: Pustaka Pelajar, 1996), 60. 
Pendidikan Islam, bahwa untuk lebih memperjelas tentang nilai, maka nilai dapat dibedakan dari beberapa klasifikasi, ${ }^{24}$ antara lain dilihat dari segi kebutuhan hidup manusia, nilai menurut Abraham Maslow dapat dibedakan menjadi: 1) nilai biologis, 2) nilai keamanan, 3) nilai cinta kasih, 4) nilai harga diri, 5) nilai jati diri.

Dilihat dari kemampuan jiwa manusia untuk menangkap dan mengem-bangkannya: 1) nilai yang statik, seperti kognisi, emosi, dan psikomotor, 2) nilai yang bersifat dinamis, seperti motivasi berprestasi, motivasi berafiliasi, motivasi berkuasa.

Dilihat dari proses budaya: 1) nilai ilmu pengetahuan, 2) nilai ekonomi, 3) nilai keindahan, 4) nilai politik, 5) nilai keagamaan, 6) nilai kekeluargaan, dan 7) nilai kejasmanian.

Dilihat dari pembagian nilai: 1) nilai-nilai subyektif, 2) nilai-nilai obyektif metafisik. Nilai berdasar dari sumbernya: 1) nilai Ilahiyah ('ubudiyah dan mu'amalah), 2) nilai insaniyah, nilai yang diciptakan oleh manusia atas dasar kriteria manusia itu juga. Dilihat dari segi ruang lingkup dan keberlakuannya: 1) nilainilai universal, 2) nilai-nilai lokal.

\subsection{Nilai Aqidah}

Aqidah adalah bentuk mashdar dari kata 'aqada, ya'qidu, 'aqdan'aqidatan yang berarti simpulan, ikatan, sangkutan, perjanjian dan

${ }^{24}$ M. Chabib Thoha, Kapita Selekta Pendidikan Islam (Yogyakarta: Pustaka Pelajar, 1996), hlm. 63 kokoh. Sedang secara teknis, 'aqidah berarti iman, kepercayaan dan keyakinan. Tumbuhnya kepercayaan tentunya di dalam hati, sehingga yang dimaksud 'aqidah adalah kepercayaan yang menghujam atau tersimpul di dalam hati. ${ }^{25}$ M. Hasbi Ash Shiddiqi mengatakan 'aqidah menurut ketentuan bahasa (bahasa Arab) ialah sesuatu yang dipegang teguh dan terhunjam kuat di dalam lubuk jiwa dan tak dapat beralih darinya. ${ }^{26}$

Dari nilai akidah di atas bahwasanya menunjukan seorang guru harus memiliki akidah yang baik terhadap peserta didik serta menjaga batas batasan dalam ucapan dalam kelas, meskipun dalam penyampain materi ada kata kata yang di seleipkan agar siswa tidak bosan dengan materi yang di sampaikan, namun dari itu semua harus menjaga batasan agar peserta didik menilai kita sebagai guru mampu dengan baik menunukan akidahnya terhadap peserta didik.

\subsection{Fungsi Akidah}

Pertama, menuntun dan mengemban dasar ketuhanan yang dimiliki oleh manusia sejak lahir. Manusia sejak lahir telah memiliki potensi keberagamaan (fitrah), sehingga sepanjang hidupnya manusia membutuhkan agama dalam rangka mencari keyakinan terhadap Allah SWT. 'Aqidah Islam berperan memenuhi kebutuhan fitrah manusia

${ }^{25}$ Tadjab, Muhaimin, Abd. Mujib, Dimensi-Dimensi Studi Islam (Surabaya: Karya Abditama, 1994), 241-242

${ }^{26}$ Syahminan Zaini, Kuliah Aqidah Islam (Surabaya: Al Ikhlas, 1983), 51 
tersebut, menuntun dan mengarahkan manusia kepada keyakinan yang benar tentang Allah SWT.

Kedua, memberikan ketenangan dan ketentraman jiwa. Agama sebagai kebutuhan fitrah manusia akan senantiasa menuntut dan mendorongnya untuk terus mencarinya. 'Aqidah memberikan jawaban yang pasti, sehingga kebutuhan rohaniahnya dapat terpenuhi. Misalnya, seseorang yang berkeyakinan bahwa setiap rizki dan segala ketentuannya sudah ditetapkan oleh Allah SWT akan merasa tenang dan tidak khawatir akan rizki yang didapatnya setiap hari. Bahwa setiap orang berikhtiar untuk menjemput rizki yang telah ditetapkan merupakan sebuah kewajiban. Akan tetapi ketika telah masuk pada persolan hasil, mutlak hak prerogatif Allah SWT. Oleh karena itu, seseorang yang mempunyai 'aqidah yang mantap tidak akan pernah khawatir dan hidupnya akan senantiasa berada ketenangan.

Ketiga, memberikan pedoman hidup yang pasti. Keyakinan terhadap Allah SWT yang diberikan kepada manusia berfungsi memberikan arahan dan pedoman yang pasti, sebab aqidah menunjukan kebenaran keyakinan yang sesungguhnya. 'Aqidah memberikan pengetahuan berasal dari apa dan dari mana manusia diciptakan. Dengan mengetahui jawaban ini minimal akan memberikan manfaat bahwa tidak ada yang dapat manusia sombongkan, kecuali Yang Maha
Sombong. 'Aqidah Islam sebagai keyakinan akan membentuk perilaku bahkan mempengaruhi kehidupan seorang muslim. Abu al-A'la AlMaududi menyebutkan pengaruh aqidah tauhid sebagai berikut:

a. Menjauhkan manusia dari pandangan yang sempit dan picik;

b. Menanamkan kepercayaan terhadap diri sendiri dan tahu harga diri;

c. Menumbuhkan sifat rendah hati dan khidmat;

d. Membentuk manusia menjadi jujur dan adil;

e. Menghilangkan sifat murung dan putus asa dalam menghadapi setiap persoalan dan situasi;

f. Membentuk pendirian yang teguh, kesabaran, ketabahan dan optimisme;

g. Menanamkan sifat kesatria, semangat dan berani, tidak gentar menghadapi resiko, bahkan tidak takut kepada maut;

h. Menciptakan sikap hidup damai dan ridha;

i. Membentuk manusia menjadi patuh, taat dan disiplin menjalankan peraturan ilahi. ${ }^{27}$

\subsection{Strategi Penanaman Nilai- Nilai Pendidikan Islam pada Peserta Didik}

Secara umum, strategi merupakan garis besar untuk bertindak dalam usaha untuk

${ }^{27}$ www.lenterakita.com, diakses 21 oktober 2017 
mencapai sasaran yang telah ditentukan dan sebagai pola-pola umum kegiatan guru beserta pesera didik dalam mewujudkan kegiatan belajar mengajar untuk mencapai tujuan yang telah digariskan. ${ }^{28}$

Jika kiakaitkan Dalam dunia pendidikan, strategi diartikan sebagai perencanaan yang berisi tentang rancangan kegiatan yang didesain untuk mencapai tujuan pendidikan tertentu. Pengertian tersebut dapat disimpulkan sebagai rencana tindakan (rangkaian kegiatan) termasuk metode dan pemanfaatan sumber daya (guru maupun peserta didik) dalam penggunaan strategi sebagai upaya pencapaian tujuan pembelajaran agar tercapai dengan optimal dan baik.

\subsection{Keteladanan}

Keteladanan dalam bahasa arab disebut uswah, iswah, qudwah, qidwah yang berarti perilaku baik yang dapat ditiru oleh orang lain. ${ }^{29}$ Dalam membina dan mendidikan anak (peserta didik) tidak hanya dapat dilakukan dengan cara model-model pembelajaran modern, tapi juga dapat dilakukan dengan cara pemberian contoh yang teladan kepada orang lain. Penggunaan metode keteladanan ini dapat tercapai dengan maksimal jika seluruh keluarga lembaga pendidikan menerapkan atau mengaplikasikan dengan mantap. Misalnya seorang

\footnotetext{
${ }^{28}$ Djamar dan Zain, Strategi Belajar Mengajar (Jakarta: PT. Rieneka Cipta, 2006), 5

${ }^{29}$ Armai Arief, Pengantar Ilmu dan Metodologi Pendidikan Islam (Jakarta: Ciputat Press, 2002), 112
}

ayah yang menyuruh anaknya untuk mengerjakan ibadah shalat, sedangkan ayahnya tidak memberikan contoh dan langsung bergegas mengerjakan ibadah solat.

Dengan demikian bahwa guru sebagai teladan yang baik bagi peserta didiknya hendaknya menjaga dengan baik perbuatan maupun ucapannya sehingga naluri anak yang suka menirukan dan mencontoh dengan sendirinya akan mengerjakan apa yang dikerjakan maupun yang sarankan oleh guru. Perbuatan yang dilihat oleh anak, secara otomotasi akan masuk kepada jiwa kepribadian si anak, kemudian timbul sikap-sikap terpuji pada perilaku anak tersebut.

\subsection{Landasan Nilai Pendidikan Islam}

Secara epistemologis, pendidikan Islam diletakkan pada dasar-dasar ajaran Islam dan seluruh perangkat kebudayaannya. Dasardasar pembentukan dan pengembangan pendidikan Islam yang pertama dan utama tentu saja adalah al-Quran dan Sunnah. ${ }^{30}$ Dalam pendidikan Islam, Sunnah Nabi mempunyai dua fungsi, yaitu: (1) menjelaskan sistem pendidikan Islam yang terdapat dalam al-Qur'an yang umumnya masih bersifat global; dan (2) menyimpulkan metode pendidikan dari kehidupan Rasulululah bersama sahabat, perlakuannya terhadap anak-anak,

${ }^{30}$ Uraian mengenai kedudukan alQur`an dan Sunnah sebagai dasar pendidikan Islam dapat dilihat antara lain, Hasan Langgulun, Beberapa Pemikiran tentang Pendidikan Islam, (Bandung: Al-Ma'arif, 1980), 96-202. 
dan pendidikan keimanan yang pernah dilakukannya. ${ }^{31}$

\subsection{Keimanan dan Ketaqwaan}

Aktivitas seorang muslim di bidang apapun, menurut konsep Islam harus didedikasikan untuk meningkatkan kualitas iman dan taqwa. Sebab, itulahu ultimatepurpose manusia (QS. Al-Imran: 102). Oleh karena itu, nilai dasar pendidikan Islam adalah keimanan dan ketakwaan. Artinya, pendidikan Islam harus dapat menjadi wahana bagi peningkatan iman dan takwa anak didik. Berdasarkan niIai dasar ini, proses pendidikan Islam dijalankan berdasarkan semangat ibadah kepada Allah SWT (QS. AlDzariyat: 56). Ibadah dalam ajaran Islam memiliki korelasi positif bagi pemeliharaan dan peningkatan iman dan takwa. Setiap penganut Islam diwajibkan mencari ilmu pengetahuan untuk dipahami secara mendalam yang dalam taraf selanjutnya dikembangkan dalam kerangka ibadah guna kemaslahatan umat manusia. Menurut al-Jamaly, nilai dasar ini bertujuan mengantarkan anak didik pada kesadaran akan eksistensinya di hadapan Allah serta menyadari kcwajiban-kewajibannya. ${ }^{32}$

Dengan demikian dalam prakteknya, nilai ini juga mesti

${ }^{31}$ Abdurrahman An-Nahlawi, PrinsipPrinsip dan Metode Pendidikan lslam, Bandung: CV. Diponogoro, 1992), 47.

${ }^{32}$ Muhammad Fadhil Al-Jamaly, Nabwa Tarbiyat Mu minat (t.t.: Al-Syirkat al Thunisiyyat li al-Tauzi', 1977), 17 dijadikan landasan oleh para pendidik dalam menjalankan tugasnya. Implikasi positifnya, sekalipun para guru memiki hak-hak tertentu sebagai konsekuensi langsung dari posisinya sebagai guru, pada saat yang sama harus tetap diingat bahwa tugas mengajar adalah suatu kewajiban agama yang harus tetap dilakukan dalam rangka ibadah. Di dalam konteks ini, kejujuran, tanggung jawab, sikap dan sebagainya merupakan prinsipprinsip tawadlu' yang perlu dipegangi oleh para praktisi dalam dunia pendidikan.

\section{KESIMPULAN}

Dari urain di atas bawasanya hubungan pemikiran pendidikan $\mathrm{Al}$ Mawardi relevansinya dengan nilainilai pendidikan Islam antara batasan guru dengan murid di sekolah berkaitan dengan akhlak, rendah hati, atau tawadhu', rendah hati terhadap peserta didik. Kemudian dengan paparan di atas bahwa pemikiran alMawardi dalam bidang pendidikan banyak terkonsentrasi pada masalah kepribadian seorang pendidik, kepribadian inilah yang tampaknya yang paling utama harus ditonjolkan. Sebenarnya seorang pendidik bukan hanya harus memiliki kepribadian yang baik, tetapi harus memiliki latar belakang ilmu keguruan dan penguasaan yang baik terhadap materi pelajaran yang akan diajarkan. Namun jika hal tersebut dibandingkan dengan kepribadian, 
tampaknya al-Mawardi lebih mengutama-kan kepribadian.

Maka oleh karena itu antara nilai-nilai Islam dengan pemikiran alMawardi tersebut ada kesinambungan yang harus dimiliki oleh seorang guru terhadap peserta didik, tentunya dalam ranah di sekolah atau lembaga pendidikan pada umumnya, kemudian seorang guru tidak hanya sebatas memberikan materi saja melainkan tugasnya sebagai pembimbing, mengarahkan serta memberikan keteladanan agar siswa bisa menggapai cita-citanya. Serta memiliki ketulusan dalam mendidik.

\section{REFERENSI}

[1] Al-Ghazali. Ibya' Ulum al-Din. Cairo: Dar al-Hadis, 1998.

[2] Al-Jamaly, Muhammad Fadhil, Nabwa Tarbiyat Mu minat. t.t.: AlSyirkat al Thunisiyyat li al-Tauzi', 1977.

[3] Al-Jurjaniy, Ali bin Muhammad. Kitab al-Ta'rifat. Beirut: Dar alKutub, 1978.

[4] Al-Mawardi. Adab al-Dunya wa alDin. Cairo: Dar al-Rayan li atTurats, 1988.

[5] Al-Mawardi. Al-Hawy al-Kabir. Beirut: Dar al-Kitab al-Ilmiah, 1994.

[6] An-Nahlawi, Abdurrahman. Prinsip-Prinsip dan Metode Pendidikan Islam. Bandung: CV. Diponegoro, 1992.
[7] Arief, Armai. Pengantar Ilmu dan Metodologi Pendidikan Islam, Jakarta: Ciputat Press, 2002.

[8] Aryati, Aziza. "Pemikiran Pendidikan al-Mawardi, AlTa'lim. Vol. 15, No. 1, Januari 2016

[9] Chabib, Thoha M. Kapita Selekta Pendidikan Islam. Yogyakarta: Pustaka Pelajar, 1996.

[10]Derajat, Zakiyah. Kepribadian Guru, Jakarta: Bulan Bintang, 1980.

[11]Djamar dan Zain, Strategi Belajar Mengajar. Jakarta: PT. Rieneka Cipta, 2006.

[12]Eliade, Mircea \& Adams, Charles J. The Encyclopedia of Religion, vol. 9.

[13] Hasan Langgulun. Beberapa Pemikiran tentang Pendidikan Islam, Bandung: Al-Ma'anf, 1980.

[14]Katsir, Ibnu. Al-Bidayah $W a$ anNihayah. Cairo: Dar Al-Hadis, 1998.

[15]Muhaimin \& Mujib, Abdul. Pemikiran Pendidikan Islam: Kajian Filosofis dan Kerangka Dasar Operasionalisasinya. Bandung: Trigenda Karya, t.th.

[16]Sholeh, Muntasir M. Mencari Evidensi Islam. Jakarta: Rajawali, 1985.

[17]Sulaiman, Fathiyah Hasan. Konsep Pendidikan al-Ghazali. Jakarta: P3M, 1986.

[18]Tabrani, Rusyan A. Kemampuan Guru dalam Proses Mengajar, (Bandung: Remaja, t.t.h)

[19]Zuhairini. Sejarah Pendidikan Islam. Jakarta: Bumi Aksara, 1992. 